\title{
Yield and quality of strawberry cultivars
}

\author{
Luis Eduardo C Antunes; Nara Cristina Ristow; Ana Cristina R Krolow; Sílvia Carpenedo; Carlos \\ Reisser Júnior \\ Embrapa Clima Temperado, C. Postal 403,96001-970 Pelotas-RS; luis.eduardo@cpact.embrapa.br
}

\begin{abstract}
The strawberry cultivation is an important economic activity in the Rio Grande do Sul State, Brazil, however the number of offered cultivars to the growers is reduced. The yield and quality of strawberry (Fragaria x ananassa Duch.) cultivars Camarosa, Galexia, Earlibrite, Festival, Plarionfre and Sabrosa was evaluated under the climatic conditions of Pelotas, Rio Grande do Sul State. We determined the number, mass, total soluble solids (TSS ${ }^{\circ}$ Brix), total titratable acidity (TTA), antocianin level and fresh fruits produced in an experimental unit. We also determined the production of fruits per hectare and per plant. The statistical design used in the experiment was of completely randomized blocks with 6 treatments (cultivars) and 4 replicates where the experimental unit was composed of 8 plants. The harvest began in the first half of August, extending to the second half of December, totalling 20 weeks. Plarionfre, Earlibrite and Festival cultivars showed higher production from the first half of October until the end of the first half of November. Camarosa reached higher productivity, mass of plants and fruit weight. There were no differences between the evaluated cultivars in the levels of TSS, antocianin, ATT and $\mathrm{pH}$ during the period of evaluation.
\end{abstract}

Keywords: Fragaria $x$ ananassa Duch., productive performance, adaptation.

\section{RESUMO}

\section{Produtividade e qualidade de cultivares de morangueiro}

No estado do Rio Grande do Sul o cultivo do morangueiro é uma atividade econômica importante, entretanto o número de cultivares disponíveis no mercado é bastante reduzido. Assim buscou-se com este trabalho avaliar a produtividade e a qualidade dos frutos de cultivares de morangueiro (Fragaria x ananassa Duch.), Camarosa, Galexia, Earlibrite, Festival, Plarionfre e Sabrosa, cultivados nas condições climáticas e de solo do município de Pelotas, RS. Determinaram-se, o número, massa fresca e teor de sólidos solúveis totais (SST) (expresso em ${ }^{\circ}$ Brix), acidez total titulável (ATT) (expresso em \% de ácido cítrico) e teor de antocianinas, dos frutos produzidos por unidade experimental. Determinou-se ainda a produção acumulada de frutos (transformado em \% a cada 15 dias de colheita), produção por hectare e por planta. O experimento foi delineado em blocos inteiramente casualizados, com 6 tratamentos (cultivares) e 4 repetições onde a unidade experimental foi composta por 8 plantas. A colheita teve início na primeira quinzena de agosto, estendendo-se até a segunda quinzena de dezembro, totalizando 20 semanas. As cultivares Plarionfre, Earlibrite e Festival apresentaram maior produtividade acumulada a partir da primeira quinzena de outubro até o final da primeira quinzena de novembro, período este de maior percentual acumulado de colheita durante toda a safra. A cultivar Camarosa proporcionou maior produtividade, maior massa de fruto por planta e fruto com maior peso. Não houve diferenças para os teores de SST, pH, ATT e teores de antocianinas no decorrer de todo o período de avaliação.

Palavras-chave: Fragaria x ananassa Duch., desempenho produtivo, adaptação.

\section{(Recebido para publicação em 5 de janeiro de 2009; aceito em 3 de fevereiro de 2010)} (Received on January 5, 2009; accepted on February 3, 2010)

Cultivated strawberries belong to the family Rosaceae, in the genus Fragaria and to the species Fragaria x ananassa Duch. (Resende et al., 1999). The hybrid Fragaria x ananassa Duch. ex Rozier, resulting from natural hybridization between the species $F$. chiloensis and $F$. virginiana, is currently the most cultivated (Silva et al., 2007). The large variability between the species that compose the genetic base of Fragaria $\mathrm{x}$ ananassa allows a greater range of adaptation and quality of commercial strawberry cultivars (Passos, 1999; Santos \& Medeiros, 2003).

Large oscillations have occurred in production volume and in the area planted with strawberries in the last eight years (Kirschbaum \& Hancock, 2000; Antunes \& Reisser Junior, 2007) in the growing regions of Brazil, as a result of climatic variations, plant health problems, the market (Resende, 1999), and new cultivation techniques (Bortolozzo, 2006; Calvete et al., 2007).

The introduction of new strawberry cultivars is important since there is a natural substitution of the current varietal pattern with the adoption of cultivars with better characteristics of adaptation and management and in relation to qualitative aspects, which offer the farmers plants with better productive and qualitative characteristics and economic benefits. Genetic improvement programs concentrate their efforts in the obtaining of cultivars with plants that are easy to handle (small and erect), resistant to pests and diseases, high yielding and early, bearing big fruits with a good appearance and sweetness (Rios, 2007).

The introduction of cultivars by companies that sell plants, is a common practice adopted in the country. Meanwhile, the evaluation of the agronomic performance of these cultivars occurs in a localized manner and in those regions of interest for these companies, which makes decision- 
making difficult for the growers who do not have access to this information. Therefore, the aim of this work was to evaluate the productive performance of new strawberry cultivars (Camarosa, Galexia, Earlibrite, Festival, Plarionfre and Sabrosa) introduced in Brazil, cultivated under the edaphoclimatic conditions of the municipality of Pelotas, Rio Grande do Sul State.

\section{MATERIAL AND METHODS}

This research was carried out in the experimental field of Embrapa Clima Temperado, located in Pelotas, with coordinates $31^{\circ} 40^{\prime} 41.29^{\prime \prime} \mathrm{S}$ and $52^{\circ}$ 26 ' 22.05" W, at an altitude of $70 \mathrm{~m}$. Fertilizing and correction of $\mathrm{pH}$ of the experimental area were carried out according to the recommendations for the crop (SBCS, 2004).

Planting of the transplants was performed at the end of May 2006, where they were arranged in two lines per bed, with spacing between lines and between plants of $0.35 \mathrm{~m}$. Mulching (black polyethylene film) and tunnel and drip irrigation were utilized in the crop production. The control of plant health was achieved by monitoring the plants, where control measures were applied with the appearance of symptoms, which involved four applications of azoxystrobin-based products and two of triazol. Weed control, and removal of dry leaves or those with disease symptoms, of runners and fruits with disease symptoms, were done manually.

The evaluated cultivars were Camarosa (University of California), Galexia (California Giant Inc.), Earlibrite and Festival (University of Florida) (Chandler et al., $2000 \mathrm{ab}$ ), Plarionfre and Sabrosa (Planasa, Spain), all being short-day. The transplants utilized were imported from Chile (Camarosa) and Argentina (Galexia, Earlibrite, Festival, Plarionfre and Sabrosa).

Fruits were harvested from the first half of August to the second half of December, totalling 20 weeks. The number and fresh weight (expressed in grams) of the fruits were determined weekly. Mean fruit weight was calculated by the ratio between number and total fresh weight. We also determined the accumulated production of fruits, and yield per hectare and per plant. Only sellable fruits were considered, where those with defects, rotted or smaller than $3 \mathrm{~g}$ were discarded (Ceagesp, 2002).

In October, the following chemical characteristics of the fruits were determined: $\mathrm{pH}$, total soluble solids (TSS) expressed in ${ }^{\circ}$ Brix, total titratable acidity (TTA) expressed in percentage of citric acid, TSS/TTA ratio and level of anthocyanins (expressed in mg 100 $\mathrm{mL}^{-1}$ ) (AOAC, 1992).

The statistical design adopted was that of randomized blocks, with 6 treatments (cultivars) and 4 repetitions, where the experimental unit was composed of 8 plants. The analyzed data were submitted to analysis of variance, where they were later compared by the Scott \& Knott test at the 5\% level of significance, using the statistics program SISVAR (Ferreira, 2000).

\section{RESULTS AND DISCUSSION}

The production of the six strawberry cultivars lasted from August to December. These results are corroborated by Oliveira \& Scivittaro (2006) who in evaluating two strawberry cultivars in the region of Pelotas, Camarosa and Aromas, obtained the same production period. The beginning of the production of strawberries, for all the studied cultivars, occurred between the second half of August and first half of September, where this period characterizes the end of winter and the beginning of spring, with mean daytime temperatures not exceeding $20^{\circ} \mathrm{C}$ in the period of evaluation, and nighttime temperatures below $10^{\circ} \mathrm{C}$.

There was an increase in production from the first half of October up to the end of the first half of November, this period showing the greatest percentage of accumulated harvest during the whole harvest period (Figure 1). In this period, the cultivar Plarionfre (37\%) showed the greatest production, followed by the cultivars Earlibrite (34\%) and Festival $(33 \%)$. These results are superior to those of 'Camarosa' (30\%), the main cultivar planted in South Brazil (Antunes \& Reisser Junior, 2007).

The distribution of the production, during the period of evaluation, showed similar graphic representation, with exception of the cultivar Galexia (Figure 1). This cultivar displayed a greater production starting on the second half of October up to end of the evaluations, where there was no production peak in the month of October as observed in the other cultivars. The differences found can be attributed to the production potential of the studied cultivars and the differences with respect to requirement

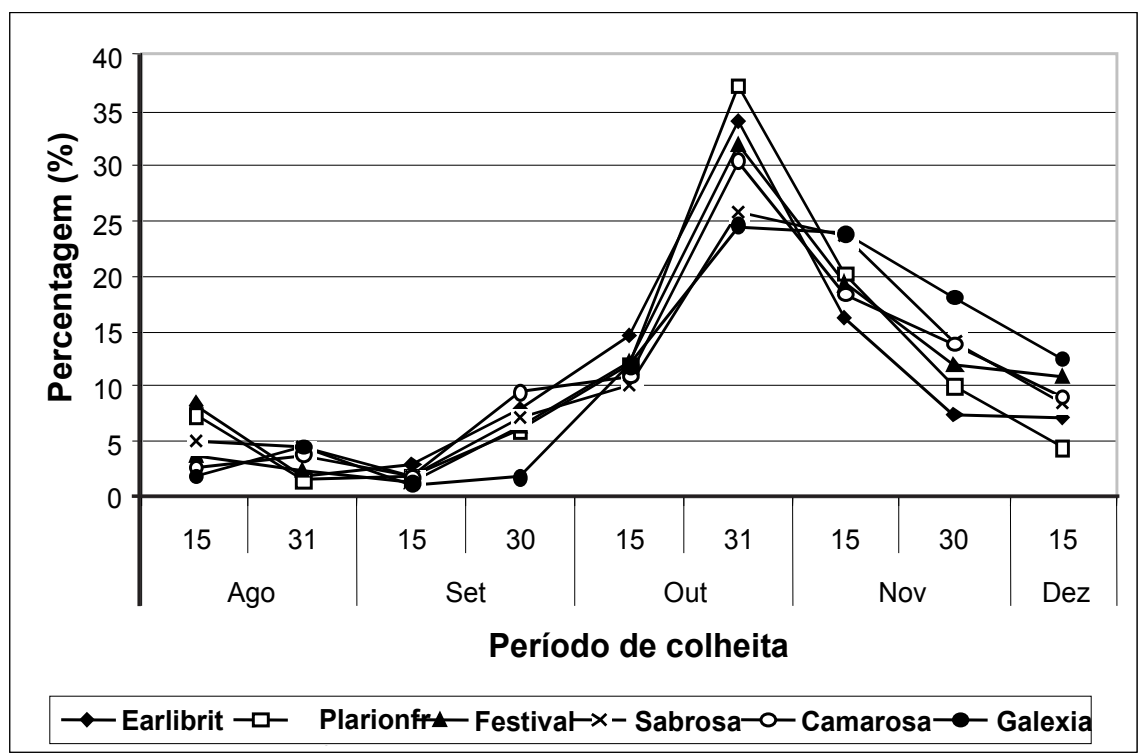

Figura 1. Desempenho produtivo (\% em relação a colheita total) ao longo do período de colheita de morangos, das cultivares Earlibrite, Plarionfre, Festival, Sabrosa, Camarosa e Galexia (productive performance during the harvest period of Earlibrite, Plarionfre, Festival, Sabrosa, Camarosa and Galexia cultivars). Pelotas, Embrapa Clima Temperado, 2008. 
Tabela 1. Produtividade $\left(\mathrm{t} \mathrm{ha}^{-1}\right)$, massa fresca média por planta e por fruto $(\mathrm{g})$ de cultivares de morangueiro (field production $\left(\mathrm{t} \mathrm{ha}^{-1}\right)$, mean fresh weight for plant and fruit $(\mathrm{g})$ of strawberry cultivars). Pelotas, Embrapa Clima Temperado, 2008.

\begin{tabular}{lccc}
\hline Cultivares & $\begin{array}{c}\text { Produtividade } \\
\left(\mathbf{t ~ h a}^{-1}\right)\end{array}$ & $\begin{array}{c}\text { Massa fresca de } \\
\text { fruto/planta }(\mathbf{g})\end{array}$ & $\begin{array}{c}\text { Massa média/fruto } \\
\mathbf{( g )}\end{array}$ \\
\hline Earlibrite & $36,06 \mathrm{c}$ & $722,45 \mathrm{c}$ & $18,95 \mathrm{~b}$ \\
Plarionfre & $30,45 \mathrm{~b}$ & $621,73 \mathrm{~d}$ & $17,19 \mathrm{c}$ \\
Festival & $37,36 \mathrm{~b}$ & $771,09 \mathrm{~b}$ & $16,84 \mathrm{c}$ \\
Sabrosa & $35,81 \mathrm{~b}$ & $716,43 \mathrm{c}$ & $18,45 \mathrm{~b}$ \\
Camarosa & $43,81 \mathrm{a}$ & $877,51 \mathrm{a}$ & $20,02 \mathrm{a}$ \\
Galexia & $37,41 \mathrm{~b}$ & $773,37 \mathrm{~b}$ & $17,51 \mathrm{c}$ \\
\hline Média & 36,81 & 747,10 & 18,20 \\
\hline CV (\%) & 7,61 & 7,50 & 2,65 \\
\hline
\end{tabular}

Médias seguidas pela mesma letra na coluna não diferem entre si, pelo teste de Scott \& Knott, a 5\% de probabilidade (means followed by the same letter in the column did not differ from each other, Scott \& Knott, $5 \%$ of probability).

Tabela 2. pH, sólidos solúveis totais (SST), acidez total titulável (ATT), razão (SST/ATT) e teor de antocianinas de cultivares de morangueiro ( $\mathrm{pH}$, total solids soluble (TSS), total titratable acidity (TTA) and antocianin level of strawberry cultivars). Pelotas, Embrapa Clima Temperado, 2008.

\begin{tabular}{|c|c|c|c|c|c|}
\hline Cultivares & pH & $\begin{array}{c}\text { SST } \\
\left({ }^{\circ} \text { Brix }\right)\end{array}$ & $\begin{array}{c}\text { ATT } \\
\text { (\% ác. cítrico) }\end{array}$ & $\begin{array}{c}\text { Ratio } \\
\text { (SST/ATT) }\end{array}$ & $\begin{array}{l}\text { Antocianinas } \\
\left(\mathrm{mg} 100 \mathrm{~mL}^{-1}\right)\end{array}$ \\
\hline Earlibrite & $3,54 \mathrm{a}$ & $7,8 \mathrm{a}$ & $0,58 \mathrm{a}$ & $13,71 \mathrm{a}$ & $28,41 \mathrm{a}$ \\
\hline Plarionte & $3,49 \mathrm{a}$ & $8,7 \mathrm{a}$ & $0,70 \mathrm{a}$ & $12,41 \mathrm{a}$ & $30,69 \mathrm{a}$ \\
\hline Festival & $3,45 \mathrm{a}$ & $7,6 \mathrm{a}$ & $0,74 \mathrm{a}$ & $10,83 \mathrm{a}$ & $34,60 \mathrm{a}$ \\
\hline Sabrosa & $3,41 \mathrm{a}$ & $8,7 \mathrm{a}$ & $0,79 \mathrm{a}$ & $10,95 \mathrm{a}$ & $26,64 \mathrm{a}$ \\
\hline Camarosa & $3,45 \mathrm{a}$ & $7,6 \mathrm{a}$ & $0,76 \mathrm{a}$ & $9,94 \mathrm{a}$ & $38,01 \mathrm{a}$ \\
\hline Galexia & $3,41 \mathrm{a}$ & $6,8 \mathrm{a}$ & $0,78 \mathrm{a}$ & $8,60 \mathrm{a}$ & $22,44 \mathrm{a}$ \\
\hline Média & 3,46 & 7,90 & 0,72 & 10,96 & 30,04 \\
\hline CV $(\%)$ & 2,15 & 7,52 & 12,43 & 20,29 & 26,98 \\
\hline
\end{tabular}

Médias seguidas pela mesma letra na coluna não diferem entre si, pelo teste de Scott \& Knott, a 5\% de probabilidade (means followed by the same letter in the column did not differ from each other, Scott \& Knott, $5 \%$ of probability).

for cold (Ronque, 1998), during the period of production of the plants. This requirement for cold varies from cultivar to cultivar, and conditions the production potential in the more demanding cultivars (Oliveira \& Scivittaro, 2009).

Besides, there is a characteristic variation of each cultivar, as shown by Antunes et al. (2006), who in evaluating cultivars of California origin found differences between them in the period of flowering and production. Fernandez et al. (2001) evaluated three strawberry cultivars (including Camarosa and Chandler) and found California cultivars superior to 'Sweet Charlie' (Florida) for the variables accumulation of dry matter, relative growth and production.
The agronomic results obtained in the experiment demonstrated that the tested cultivars displayed a productivity between 30.45 and 43.81 $\mathrm{t} \mathrm{ha}^{-1}$ (Table 1). Meanwhile, there were significant differences in the production potential of the evaluated cultivars. The cultivar Camarosa showed the greatest production with $877.51 \mathrm{~g}$ plant $^{-1}$, followed by cultivars Galexia and Festival, with 773.37 and 771.09 g plant $^{-1}$, respectively. The cultivar Plarionfre showed the lowest production with $621.73 \mathrm{~g} \mathrm{plant}^{-1}$. These results are superior to those obtained by Conti et al. (2002) who observed a production yield for all the strawberry cultivars evaluated in the São Paulo State in which none reached 500 g plant $^{-1}$.
In relation to the mean fruit weight per plant, 'Camarosa' (20.28 g) showed the highest weight, while 'Festival' had the lowest weight with $16.83 \mathrm{~g}$. These values are superior to those reported by Oliveira \& Scivittaro (2006, 2008) in the region of Pelotas, for 'Camarosa', 'Aromas', 'Diamante' and 'Cegnidarem'.

The cultivar Camarosa showed the greatest acumulated production in the cycle (43.81 t ha-1) (Table 1), and the cultivars Plarionfre, Earlibrite and Festival showed greater production from the first half of October up to the end of the first half of November (Figure 1). Chandler et al. (2000 a) reported that 'Earlibrite' had a production potential equal to that of 'Camarosa', but with greater fruit weight. 'Festival' was inferior in production per plant and fruit weight (Chandler et al., 2000 b).

In relation to the mean weight per fruit, the cultivar Camarosa, followed by the cultivars Earlibrite and Sabrosa, showed greater fruit weight $(20.02$ $\mathrm{g}$ ), and although the cultivar Festival showed one of the highest productions, it had the lowest mean weight per fruit among the cultivars (Table 1). These data are superior to those obtained by Oliveira \& Scivitarro (2008) who in evaluating the cultivars Aromas, Diamante and Cegnidarem, in the region of Pelotas, found maximal values of $18.5 \mathrm{~g} \mathrm{fruit}^{-1}$.

The chemical characteristics of the strawberries did not differ statistically between the cultivars. With exception of the cultivar Galexia, the tested cultivars exceeded the values recommended for an acceptable flavor which corresponds to a minimum of $7 \%$ soluble solids (Namesny, 1999; Mitchell et al., 1996), especially the cultivar Plarionfre.

The ratio TSS/TTA is one of the most utilized ways for the evaluation of the flavor of fruits. Although the statistical test has grouped all the cultivars together, Earlibrite showed the highest values for this variable and the cultivar Galexia displayed the lowest TSS/TTA ratio in the group, due to the low levels of TSS and elevated acidity. The variables $\mathrm{pH}$ and anthocyanin levels did not show significant differences between the tested cultivars. 


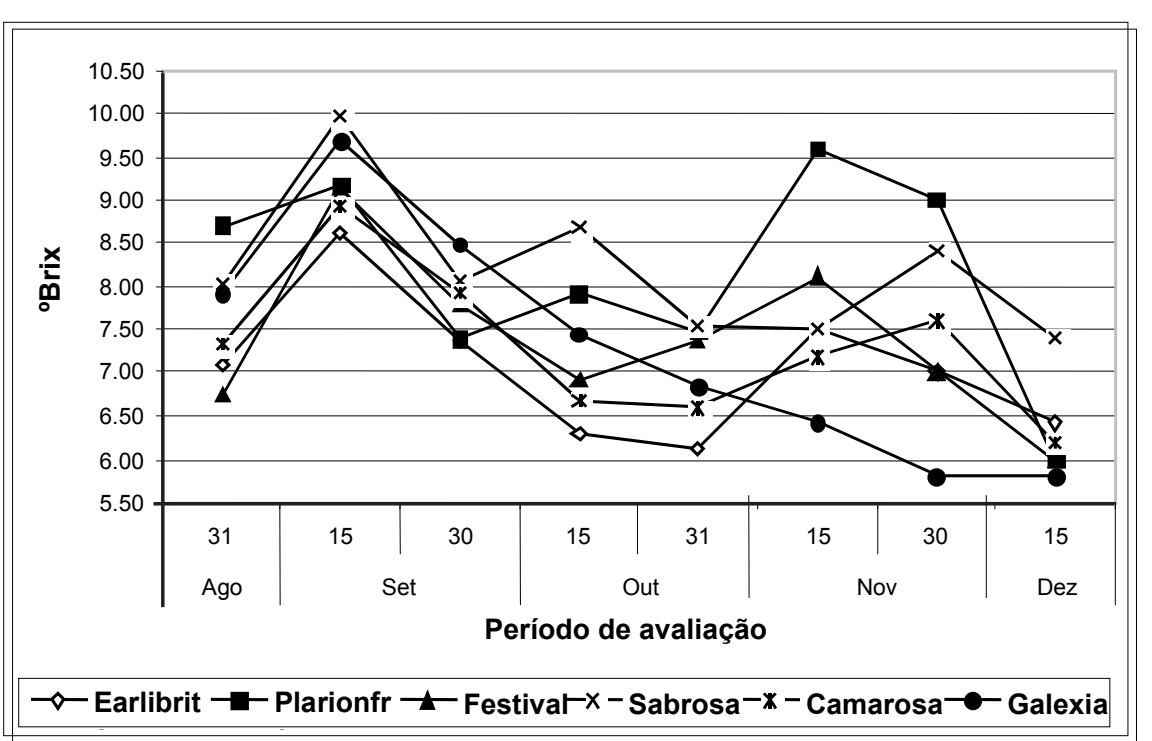

Figura 2. Sólidos solúveis totais ( ${ }^{\circ}$ Brix) ao longo do período de colheita das cultivares de morango Earlibrite, Plarionfre, Festival, Sabrosa, Camarosa e Galexia (total soluble solids ( ${ }^{\circ}$ Brix) over the period of harvest of the Earlibrite, Plarionfre, Festival, Sabrosa, Camarosa and Galexia strawberries cultivars). Embrapa Clima Temperado, Pelotas-RS, 2008.

In relation to the TSS levels during the evaluation period, the cultivars showed a similar behavior, with small variations (Figure 2). There was a decline in the levels of TSS starting in the second half of September, with the increase in temperature and photoperiod. According to Darnell (2003), the increase of the length of the day increases the photosynthetic process, while reducing the period between flowering and the harvest of the fruit, which in winter is between 30 and 45 days and in spring between 25 and 30 days. This reduction in the permanence of the fruit on the plant diminishes the accumulation of sugars. The cultivars Plarionfre, Sabrosa and Festival showed the highest values of soluble solids during the entire period of evaluation, while Earlibrite showed the lowest values. According to Chandler et al. (2000 b), Festival was superior to Camarosa with respect to sweetness. However, the cultivar Earlibrite showed the lowest values, which contradicts the findings of Chandler et al. (2000 a) who stated that this cultivar is sweeter than Sweet Charlie and Camarosa. According to Chitarra \& Chitarra (2005), TSS levels vary with the species, cultivar, stage of maturation and climate, with a range of 2 to $25 \%$, with mean values between 8 and 14\%.

The levels of anthocyanins did not differ between the cultivars (Table 2), which is in line with the findings of similar results to those in this work for Camarosa (38.01 mg $\left.100 \mathrm{~g} \mathrm{~g}^{-1}\right)$. Meanwhile, these authors obtained higher values for the strawberry cultivars Serrano (56 mg $100 \mathrm{~g}^{-1}$ ) and Comander (54 mg $100 \mathrm{~g}^{-1}$ ), and according to these authors, there is a tendency of the consumer market to demand fruits with higher indices of this group of and differentiates the production of strawberries.

Based on the obtained information, Camarosa is the most productive of the evaluated cultivars, showing greater production per plant and per hectare and fruits with greater weight, continuing to be indicated for planting in the region of Pelotas. There is no qualitative difference between the evaluated cultivars for levels of total soluble solids, $\mathrm{pH}$, total titratable acidity, and ratio and level of anthocyanins.

\section{ACKNOWLEDGEMENTS}

Financial support was provided by Fundação de Amparo à Pesquisa do Estado do Rio Grande do Sul (FAPERGS) and Conselho Nacional de Desenvolvimento Científico e Calvete et al. (2008) who obtained natural antioxidants, which appraises
Tecnológico $(\mathrm{CNPq})$.

\section{REFERENCES}

ANTUNES LEC; REISSER JÚNIOR C. 2007. Fragole, i prodottori brasiliani mirano all'esportazione in Europa. Frutticoltura 69: 60-65.

ANTUNES LEC; RISTOW NC; KROLOW ACR; CARPENEDO S; REISSER JUNIOR C. 2008 Comportamento produtivo de novas cultivares de morangueiro na região de Pelotas, $R S$. Pelotas: Embrapa Clima Temperado. 20 p. (Embrapa Clima Temperado. Boletim de pesquisa e desenvolvimento, 70).

ANTUNES OT; CALVETE EO; ROCHA HC; NIENOW AA; MARIANI F; WESP CL. 2006. Floração, frutificação e maturação de frutos de morangueiro cultivados em ambiente protegido Horticultura Brasileira 24: 426-430.

A.O.A.C. 1992. Official methods of analysis of the association of official analytical chemistry. 11 ed. Washington: AOAC, 1115p.

BORTOLOZZO AR. 2006. Produção de morangos em substrato artificial, em ambiente protegido. In: ANTUNES LEC; RASEIRA MCB (eds), Palestras do III Simpósio Nacional do Morango; II Encontro de Pequenas Frutas Nativas do Mercosul, Pelotas: Embrapa Clima Temperado. 55-60 (Documentos, 171).

CALVETE EO; MARIANI F; WESP CL; NIENOW AA; CASTILHOS T; CECCHETTI D. 2008. Fenologia, produção e teor de antocianinas de cultivares de morangueiro em ambiente protegido. Revista Brasileira de Fruticultura 30: 396-401.

CALVETE EO; NIENOW AA; WESP CL; CESTONARO L; MARIANI F; FIOREZE I; CECCHETTI D; CASTILHOS T. 2007. Produção hidropônica de morangueiro em sistema de colunas verticais, sob cultivo protegido. Revista Brasileira de Fruticultura 29: 524-529.

CHANDLER CK; LEGARD DE; DUNINGAN DD; CROCKER TE; SIMS CA. 2000. 'Strawberry Earlibrite' Strawberry. HortScience 35: 1363-1365a.

CHANDLER CK; LEGARD DE; DUNINGAN DD; CROCKER TE; SIMS CA. 2000. 'Strawberry Festival' Strawberry. HortScience 35: 1366-1367b.

CEAGESP. 2002. Normas de classificação de morango. São Paulo: CQH/CEAGESP. Documento, 22. 6 p.

CHITARRA MIF; CHITARRA AB. 2005. Póscolheita de frutos e hortaliças: fisiologia e manuseio. Lavras: UFLA-Faepe. 785 p.

CONTI JH; MINAMI K; TAVARES FCA. 2002. Produção e qualidade de frutos de morango em ensaios conduzidos em Atibaia e Piracicaba. Horticultura Brasileira 20: 10-17.

DARNELL RL 2003. Strawberry growth and development. In: CHILDERS NF (ed). The strawberry: a book for growers, others. Gainesville: University of Florida. p. 3-10.

FERNANDEZ GE; BUTLER LM; LOUWS FJ. 2001. Strawberry growth and development in an annual plasticulture system. HortScience 
36: 1219-1223.

FERREIRA DF. 2000. Análises estatísticas por meio do Sisvar para Windows versão 4.0. In: REUNIÃO ANUAL DA REGIÃO BRASILEIRA DA SOCIEDADE INTERNACIONAL DE BIOMETRIA, Anais... São Carlos: UFSCar. 45: 255-258.

KIRSCHBAUM D; HANCOCK JF. 2000. The strawberry industry in South America. HortScience 35: 807-811.

MITCHELL FG; MITCHAM E.; THOMPSON JE; WELCH N. 1996. Handling strawberries for fresh market. Oakland, CA: University of California, $14 \mathrm{p}$.

NAMESNYA. 1999. Posrecolección de hortalizas: III Hortalizas de fruto. España, 302 p.

OLIVEIRARP; SCIVITARRO W. 2008. Produção de morangueiro cv. "Cegnidarem" sob túnel plástico. Ciência Rural. s.n.p.

OLIVEIRA RP; SCIVITTARO WB. 2006. Desempenho produtivo de mudas nacionais e importadas de morangueiro. Revista Brasileira de Fruticultura 28: 520-522.

OLIVEIRA RP; SCIVITTARO WB. 2009. Produção de frutos de morango em função de diferentes períodos de vernalização das mudas. Horticultura Brasileira 27: 091-095.

PASSOS FA. 1999. Melhoramento do morangueiro no Instituto Agronômico de Campinas. In: DUARTE FILHO J; CANÇADO GMA; REGINA MA; ANTUNES LEC; FADINI MAM; (eds). Morango: tecnologia de produção e processamento. Caldas: EPAMIG. 259-264.

RESENDE LMA; MASCARENHAS MHT; PAIVA BM. 1999. Panorama da produção e comercialização do morango. Informe Agropecuário 20: 5-17.

RIOS SA. 2007. Melhoramento genético do morangueiro. Informe Agropecuário 28: 14-19.

RONQUE ERV. 1998. A cultura do morangueiro: revisão e prática. Paraná: EMATER. 206p.

SANTOS AM; MEDEIROS ARM. 2003. Morango: Produção. Frutas do Brasil. Embrapa 40: 81p.

SILVA AF; DIAS MSC; MARO LAC. 2007. Botânica e fisiologia do morangueiro. Informe Agropecuário 28: 7-13.

SBCS-SOCIEDADE BRASILEIRADE CIÊNCIA DO SOLO. Comissão de Química e Fertilidade do Solo. 2004. Manual de adubação e calagem para os Estados do Rio Grande do Sul e Santa Catarina. Porto Alegre: SBCS/CQFS. 400p. 